\title{
Discovery of the Smallest Lace Bug from Mid-Cretaceous of Northern Myanmar Supports the Hypothesis of a Miniaturization Phenomenon of Insects in Kachin Amber (Hemiptera: Heteroptera: Tingidae)
}

\author{
Jun Souma $^{1}\left(\mathbb{D}\right.$, Shûhei Yamamoto ${ }^{2, *(\mathbb{D})}$ and Yui Takahashi ${ }^{3}$ \\ 1 Entomological Laboratory, Graduate School of Bioresource and Bioenvironmental Sciences, \\ Kyushu University, Motooka 744, Fukuoka 819-0395, Japan; souma.jun.444@s.kyushu-u.ac.jp \\ 2 Hokkaido University Museum, Hokkaido University, Kita 8, Nishi 5, Kita-ku, Sapporo 060-0808, Japan \\ 3 Keio Yochisha Elementary School, Ebisu 2-35-1, Shibuya 150-0013, Japan; y.takahashi.geol@gmail.com \\ * Correspondence: syamamoto@fieldmuseum.org
}

Citation: Souma, J.; Yamamoto, S.; Takahashi, Y. Discovery of the Smallest Lace Bug from Mid-Cretaceous of Northern Myanmar Supports the Hypothesis of a Miniaturization Phenomenon of Insects in Kachin Amber (Hemiptera: Heteroptera: Tingidae). Taxonomy 2021, 1, 60-68. https://doi.org/ $10.3390 /$ taxonomy 1020007

Academic Editor:

Adolfo Cordero-Rivera

Received: 2 April 2021

Accepted: 21 April 2021

Published: 24 April 2021

Publisher's Note: MDPI stays neutral with regard to jurisdictional claims in published maps and institutional affiliations.

Copyright: (c) 2021 by the authors. Licensee MDPI, Basel, Switzerland. This article is an open access article distributed under the terms and conditions of the Creative Commons Attribution (CC BY) license (https:// creativecommons.org/licenses/by/ $4.0 /)$.

\begin{abstract}
A total of 14 species in seven tingid genera have been described from the mid-Cretaceous Burmese (Kachin) amber from northern Myanmar, with very distinct paleofauna. Here, a new species of a new genus, Burmavianaida anomalocapitata gen. et sp. nov., is described from Kachin amber. This new species can be readily distinguished from the other described tingid taxa by the apparently smaller body and the structures of the pronotum and hemelytron. Burmavianaida gen. nov. shares the diagnostic characters with two clades composed of three extant subfamilies (Cantacaderinae + Tinginae) and Vianaidinae and may represent an extinct clade distinct from them. To the best of our knowledge, B. anomalocapitata sp. nov. is the smallest species of Tingidae among over 2600 described species. Our new finding supports the hypothesis of the miniaturization phenomenon of insects in Kachin amber, as suggested by previous studies.
\end{abstract}

Keywords: taxonomy; new genus; new species; miniaturization; Mesozoic; Myanmar; Cenomanian; Kachin amber

\section{Introduction}

Members of the phytophagous true bug family Tingidae Laporte, 1832 (Hemiptera: Heteroptera) are generally called lace bugs because of the distinct lacelike network of areolae adorning the pronotum and hemelytron. They are distributed across all zoogeographical regions and are particularly diverse in tropical areas, with approximately 2600 extant described species [1]. Most members feed on the leaves of angiosperms. Lace bugs are generally small insects, with body lengths ranging from approximately 2.0 to $8.0 \mathrm{~mm}$. Among extant taxa, three subfamilies have been recognized: Cantacaderinae Stål, 1873, Tinginae Laporte, 1832, and Vianaidinae Kormilev, 1955 [1-4].

Fossil lace bugs have been primarily described based on amber inclusions, not based on compression fossils, possibly due to their small and fragile bodies. However, fossil records of lace bugs based on well-preserved amber material are poorly known. The earliest fossil has been described from the Middle Triassic of Monte San Giorgio, Switzerland [5], but the family placement of this fossil is doubtful [1]. As there is no fossil record from the Jurassic, the occurrence of this Triassic fossil should be carefully re-evaluated in future. In the Lower Cretaceous, four species have been recorded from France, Mongolia, and Russia [6-9]. A total of 14 species from seven genera have been identified from the midCretaceous Burmese (Kachin) amber from northern Myanmar to date [10-15].

The insect paleofauna of Kachin amber is particularly interesting in comparison with that of the present day. For instance, some fossil species represent a miniaturization 
phenomenon compared to extant taxa [16-18]. On the other hand, no fossil occurrence showing such miniaturization has been documented in Tingidae to date.

Recently, we found an interesting lace bug fossil, which is apparently smaller than both extant and extinct taxa, from the same amber deposit. Here, we describe Burmavianaida anomalocapitata gen. et sp. nov., as the 15th species of the eighth genus from Kachin amber. This fossil lace bug has the exceptionally smallest body among Tingidae and shares the diagnostic characters with two major clades composed of three extant subfamilies, i.e., (Cantacaderinae + Tinginae) and Vianaidinae, such as the areolate pronotum and hemelytron and the well-developed scutellum. Our discovery is of a novel phylogenetic significance and further reinforcing a possible miniaturization trend of lace bugs in the mid-Cretaceous.

\section{Materials and Methods}

The fossil specimen used in the present study is embedded in the mid-Cretaceous Kachin amber (Burmese amber), from amber deposits near Noije Bum Village $\left(26^{\circ} 20^{\prime} \mathrm{N}\right.$, $96^{\circ} 36^{\prime}$ E) in the Hukawng Valley, Kachin, northern Myanmar. Based on radiometric U-Pb dating and paleontological findings, the date of Kachin amber has been considered to be of the mid-Cretaceous of the Albian-Cenomanian boundary, or slightly older [19-22].

The amber piece with the fossil inclusion was ground under emery papers with different grain sizes. Morphological characters were examined using a stereomicroscope (SZ60; Olympus, Tokyo, Japan). Photographs were taken using a digital camera (EOS 80D; Canon, Tokyo, Japan), attached with a macro lens (MP-E 65 mm F2.8, 1-5×; Canon) and with twin flash as a light source (MT-24EX; Canon). When the amber piece was photographed, it was completely immersed in clove oil (Wako Pure Chemical Industries, Osaka, Japan) to eliminate reflections. Photomontage was carried out using Helicon Focus 7.6.4 (Helicon Soft, Kharkiv, Ukraine).

The morphological terms and the higher classifications of Tingidae were generally followed in accordance with the previous monographs $[1,23]$. The lengths and ratios of the body parts were measured using a micrometer with an ocular grid. All measurements are presented in millimeters.

The type specimen used in this study was deposited at the American Museum of Natural History, New York, NY, USA (AMNH; head of collections, D. Grimaldi), with the assigned number of AMNH Bu-SY29. This published work and the nomenclatural acts it contains have been registered in ZooBank, the proposed online registration system for the International Code of Zoological Nomenclature (ICZN). The ZooBank LSIDs (Life Science Identifiers) can be resolved and the associated information can be viewed through any standard web browser by appending the LSID to the prefix 'http:/ / zoobank.org/ accessed on 22 April 2021'. The LSIDs for this publication are: urn:lsid:zoobank.org:pub:241913A73EB2-4FB6-A6B7-13B726250CC1; urn:lsid:zoobank.org:act:8D605B17-0BAB-42E9-963AD51C1E6A56AA; urn:lsid:zoobank.org:act:A1AD0116-0101-4211-AC26-74DC54458C76. The higher-resolution images used in this study have been deposited in the figshare (https: / / doi.org/10.6084/m9.figshare.14465400; accessed on 22 April 2021) and Zenodo repositories (https:/ / doi.org/10.5281/zenodo.4709792; accessed on 22 April 2021).

\section{Results}

\subsection{Systematic Palaeontology}

Order Hemiptera Linnaeus, 1758

Suborder Heteroptera Latreille, 1810

Infraorder Cimicomorpha Leston, Pendergrast and Southwood, 1954

Superfamily Miroidea Hann, 1833

Family Tingidae Laporte, 1832

Subfamily not assigned, tentatively between Vianaidinae and (Tinginae + Cantacaderinae).

\subsubsection{Burmavianaida gen. nov.}


Type species: Burmavianaida anomalocapitata sp. nov., by monotypy and present designation.

Diagnosis. Recognized among other tingid genera by a combination of the following characters: head elongate, longer than its maximum width across compound eyes; antennal segment II longer than segment I, subequal in length to segment III; segment IV longest among antennal segments; paranotum distinctly areolate, present along entire length of lateral margin of pronotum; scutellum well-developed, exposed; and hemelytron distinctly areolate, with membranous surface on sutural area.

Description. Macropterous morph. Body (Figure 1A-C) oblong, covered with pubescence. Head (Figures 2A,B and 3B,C) elongate, longer than its maximum width across compound eyes, without spine. Compound eye protruding laterad. Antenniferous tubercle nearly straight, obtuse at apex. Antenna smooth on surface; segments I cylindrical, shortest among antennal segments, separated from each other at their bases; segment II clavate, longer than segment I, slightly shorter than segment III; segment III cylindrical; segment IV fusiform, longest among antennal segments. Buccula extending from clypeus to posterior margin of head, without distinct areolae. Rostrum reaching posterior margin of abdominal sternite IV.

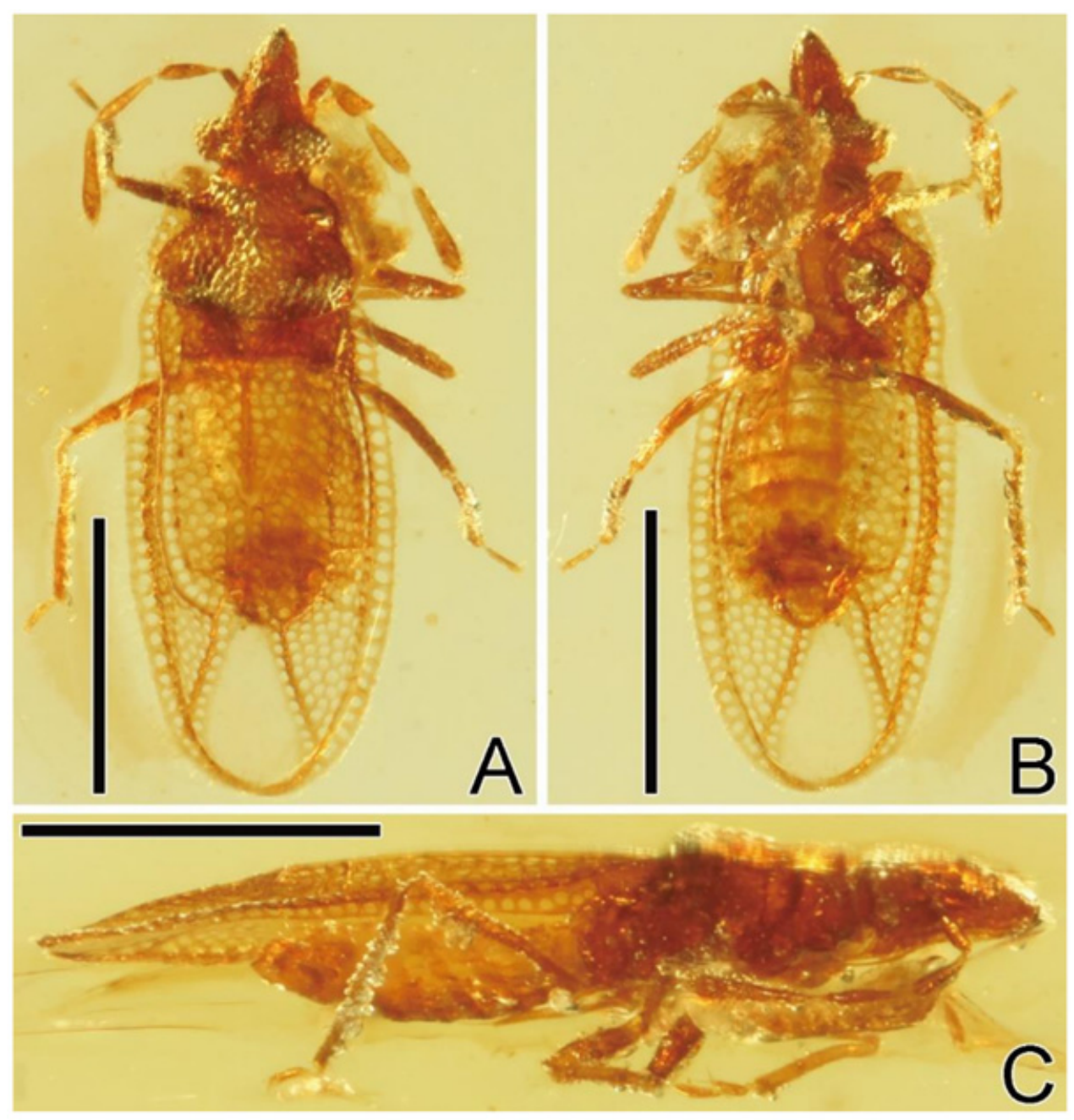

Figure 1. Habitus images of Burmavianaida anomalocapitata gen. et sp. nov. from mid-Cretaceous Kachin amber (holotype, AMNH Bu-SY29): dorsal, ventral and lateral views (A-C). Scale bars: $0.5 \mathrm{~mm}$. 

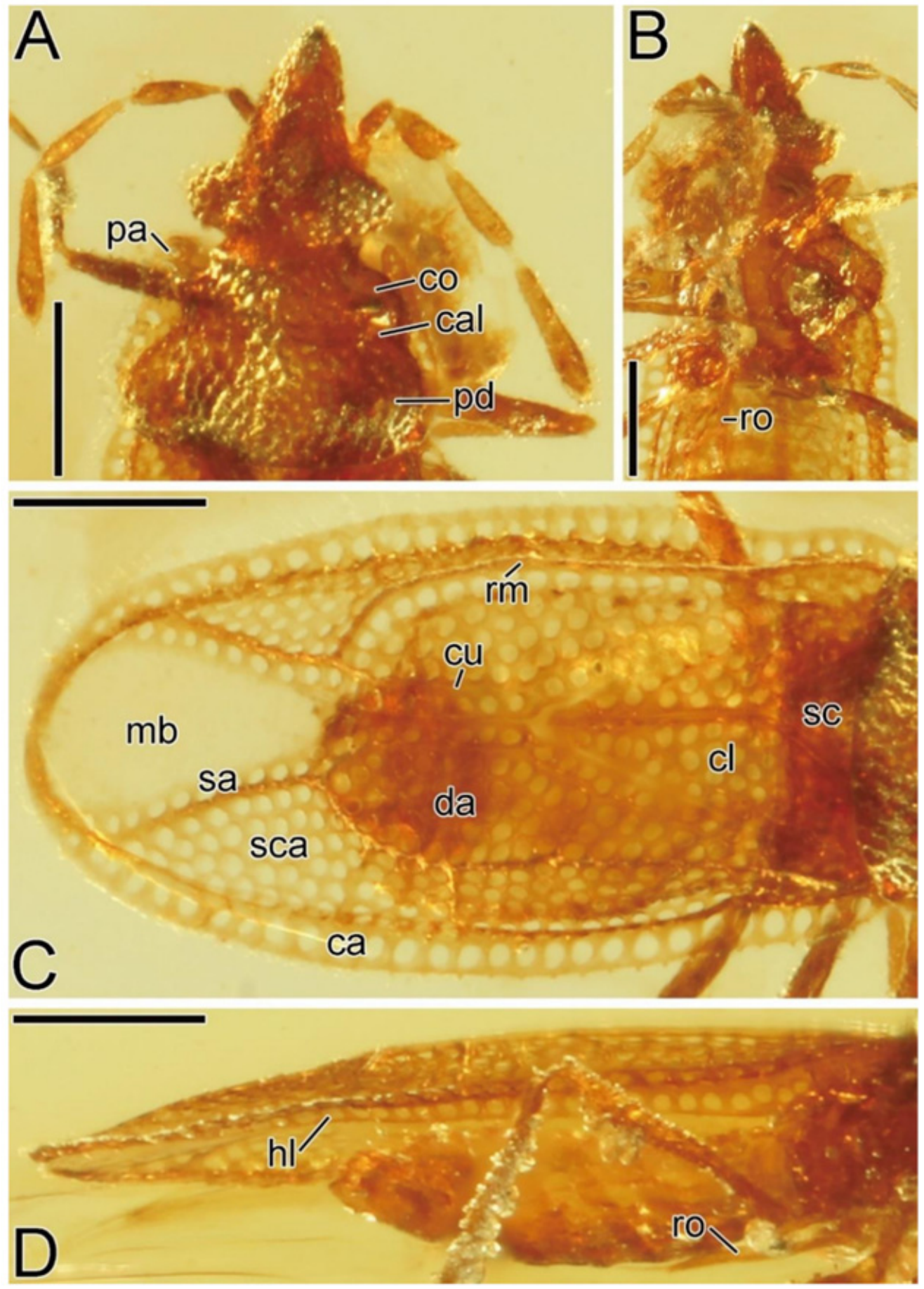

Figure 2. Detailed morphological images of Burmavianaida anomalocapitata gen. et sp. nov. from mid-Cretaceous Kachin amber (holotype, AMNH Bu-SY29): head and pronotum, dorsal view (A); rostrum, ventral view (B); hemelytron, dorsal and lateral views (C,D). Abbreviations: ca, costal area; cal, calli; cl, clavus; co, collar; cu, Cu (cubital) vein; da, discoidal area; hl, hypocostal lamina; mb, membrane; pa, paranotum; pd, pronotal disc; rm, R + M (radiomedial) vein; ro, rostrum; sa, sutural area; sc, scutellum; sca, subcostal area. Scale bars: $0.2 \mathrm{~mm}$. 


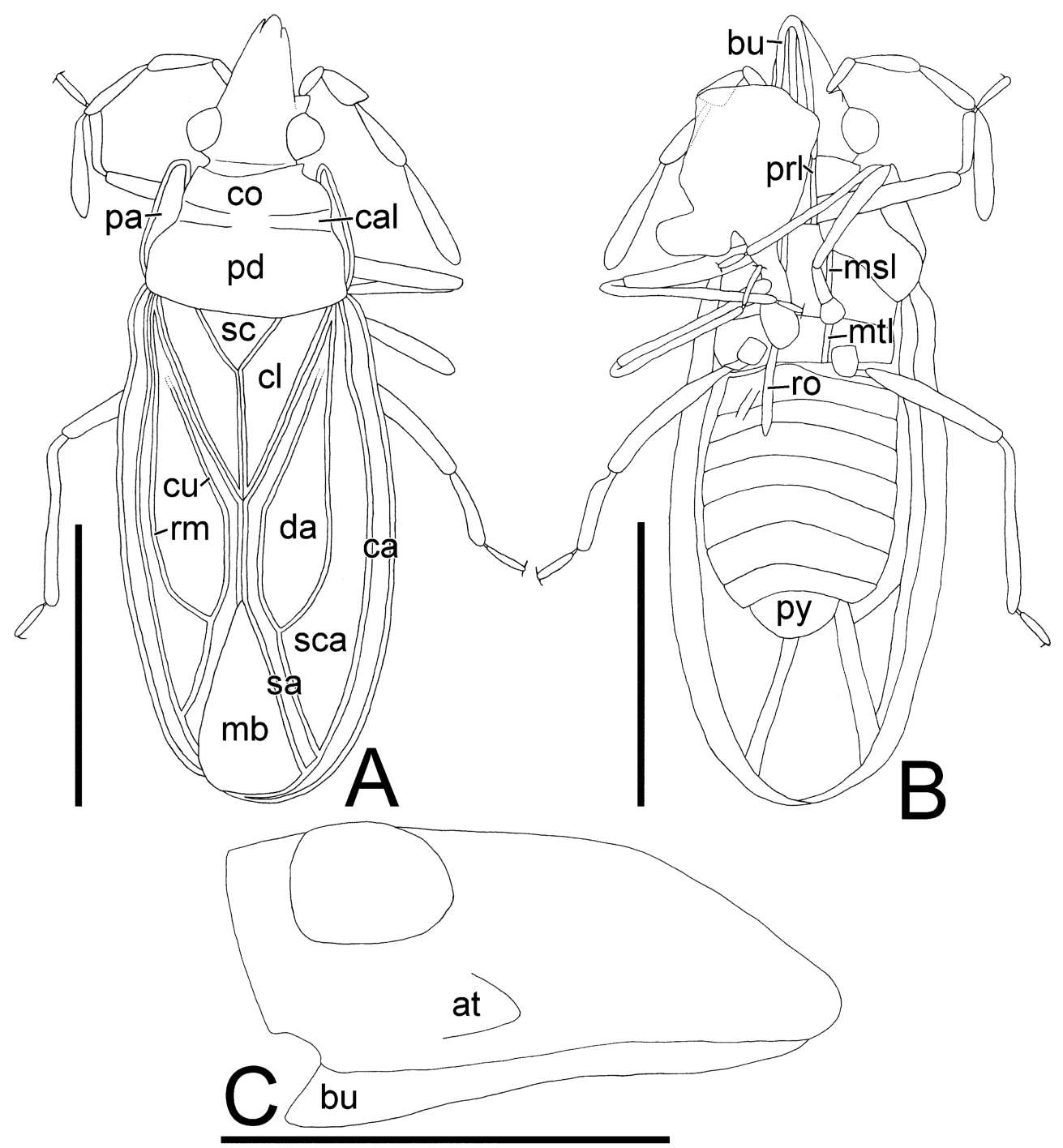

Figure 3. Line drawings of Burmavianaida anomalocapitata gen. et sp. nov. from mid-Cretaceous Kachin amber (holotype, AMNH Bu-SY29): general habitus, dorsal and ventral views (A,B); head, lateral view (C). Abbreviations: at, antenniferous tubercle; bu, buccula; ca, costal area; cal, calli; $\mathrm{cl}$, clavus; co, collar; cu, Cu (cubital) vein; da, discoidal area; hl, hypocostal lamina; mb, membrane; $\mathrm{msl}$, mesosternal lamina; $\mathrm{mtl}$, metasternal lamina; pa, paranotum; pd, pronotal disc; prl, prosternal lamina; rm, R+M (radiomedial) vein; ro, rostrum; py, pygophore; sa, sutural area; sc, scutellum; sca, subcostal area. Ventral surface partly obscured by impurity. Scale bars: A, B, $0.5 \mathrm{~mm} ; \mathrm{C}, 0.2 \mathrm{~mm}$.

Pronotum (Figures 2A and 3A) flat; lateral margin with paranotum throughout its length. Pronotal disc coarsely punctate. Hood absent. Collar coarsely punctate; anterior margin nearly straight. Pronotal carina absent. Calli smooth on surface. Paranotum distinctly areolate, laminate; anterolateral angle protruding anteriad; lateral margin nearly straight. Posterior process absent. Scutellum (Figure 2C) well-developed, coarsely punctate, completely visible in dorsal view.

Hemelytron (Figures 2C,D and 3A) distinctly areolate, with membranous surface on sutural area, considerably extending beyond apex of abdomen; anterior margin gently curved outward; $\mathrm{R}+\mathrm{M}$ (radiomedial) vein carinate; basal part of $\mathrm{Cu}$ (cubital) vein indistinct, separated from $\mathrm{R}+\mathrm{M}$ vein; clavus well-developed; stenocostal area absent; costal area distinct, narrower than subcostal area at widest part of each, slightly reflexed upward in basal part; subcostal area subhorizontal, without transverse vein, as wide as discoidal area at widest part of each; discoidal area flat, distinctly expanding beyond middle of 
hemelytron, without transverse vein; membrane without vein; hypocostal lamina with a single row of areolae throughout its length.

Thoracic pleura smooth on surface (Figure 1C). Ostiolar peritreme protruding Tshaped. Sternal laminae (Figure 3B) nearly straight. Legs smooth on surface; femur thickest at middle; tibia cylindrical; tarsi two-segmented.

Abdomen (Figures 1B and 3B) ellipsoidal, 1.4 times as long as its maximum width; sternites without transverse furrow. Pygophore symmetrical, compressed dorsoventrally, semicircular in ventral view.

Brachypterous morph unknown.

Remarks. Burmavianaida gen. nov. resembles Pterovianaida Montemayor and Carpintero, 2007 [24] in general appearance, but the former can easily be distinguished from the latter by the elongated head and the distinctly areolate paranotum and hemelytron (Figure $1 \mathrm{~A}-\mathrm{C}$ ).

Etymology. The genus epithet is composed by the word Burma (Myanmar) and the subfamily Vianaidinae, referring to the origin and the related extant taxon resembling in general appearance; the gender is feminine.

\subsubsection{Burmavianaida anomalocapitata sp. nov.}

LSID: urn:lsid:zoobank.org:act:A1AD0116-0101-4211-AC26-74DC54458C76

(Figures 1-3)

Type series. Holotype (AMNH Bu-SY29): a well-preserved specimen of male in a $7.9 \times 4.5 \times 3.0 \mathrm{~mm}$ parallelepipedal piece of Burmese (Kachin) amber, lateral and ventral surface structures partly obscured by impurities and small air bubbles. Deposited at the American Museum of Natural History, New York, NY, USA.

Locality and horizon. Hukawng Valley in the northern state of Kachin, northern Myanmar; mid-Cretaceous (late Albian to early Cenomanian).

Diagnosis. Recognized among other tingid species by the characteristics mentioned in the Diagnosis section of Burmavianaida gen. nov.

Description. Male. Head, compound eye, pronotum, scutellum, thoracic pleura, thoracic sternum, and legs dark brown; antenna, paranotum, hemelytron, and abdomen light brown; areolae of paranotum and hemelytron transparent (Figure 1A-C).

Body (Figure 1A-C) 2.8 times as long as maximum width across hemelytra. Head (Figures 2A,B and 3B,C) 1.2 times as long as maximum width across compound eyes. Ratio of lengths from antennal segments I to IV as 1.0:1.8:2.2:2.8.

Pronotum (Figures 2A and 3A) 1.6 times as long as maximum width across paranota. Paranotum with a single row of areolae throughout its length. Scutellum (Figure 2C) as long as its maximum width.

Hemelytron (Figures 2C,D and 3A) 3.3 times as long as its maximum width; maximum width across hemelytra 1.3 times as wide as maximum width across paranota; clavus with 4 rows of areolae at widest part; costal area with a single row of areolae throughout its length; subcostal area with 5 rows of areolae at widest part; discoidal area with 5 rows of areolae at widest part; sutural area with a single row of areolae throughout its length.

Measurements. Body length with hemelytra $1.40 \mathrm{~mm}$; maximum width across hemelytra $0.50 \mathrm{~mm}$; head length $0.28 \mathrm{~mm}$; head width across compound eyes $0.24 \mathrm{~mm}$; length of antennal segments I to IV: $0.06,0.11,0.13$, and $0.17 \mathrm{~mm}$, respectively; pronotal length $0.25 \mathrm{~mm}$; pronotal width across paranota $0.41 \mathrm{~mm}$; scutellum length $0.08 \mathrm{~mm}$; maximum width of scutellum $0.08 \mathrm{~mm}$; hemelytral length $0.91 \mathrm{~mm}$; maximum width of hemelytron $0.29 \mathrm{~mm}$.

Female unknown.

Remarks. In addition to the diagnostic characters of the genus, Burmavianaida anomalocapitata sp. nov. is easily distinguished from the other tingid species by its shortest body length $(1.4 \mathrm{~mm}$ ) (Figure 1A-C). 
Etymology. The species epithet is composed by the Latin adjective anomalus (meaning irregular) and the Latin noun caput (meaning head), referring to the features of the distinctive elongate head.

\section{Discussion}

Burmavianaida gen. nov. unambiguously belongs to the family Tingidae and has two characters apomorphic to Tingidae [25]: the sternal laminae (Figures 2B and $3 \mathrm{~B}, \mathrm{C}$ ), and the buccula extending from the clypeus to the posterior margin of the head. Additionally, the general habitus of this new genus is clearly of a typical tingid with a distinctly areolate paranotum and hemelytron (Figure 1A-C). The confident subfamilial placement of Burmavianaida gen. nov. within Tingidae is rather challenging, although the fossil is wellpreserved with several important characters visible. This new genus is distinctly different from an extinct tingid subfamily, Tingiometrinae Heiss, Golub and Popov, 2015 [26] by the following characteristics: antennal segment II subequal in length to segment III; segment IV longest among antennal segments; and hemelytron with membranous surface on sutural area. In comparison with the extant three subfamilies of Tingidae (i.e., Cantacaderinae, Tinginae, and Vianaidinae), Burmavianaida gen. nov. resembles in general habitus and shares the following diagnostic characters with Vianaidinae [1]: antennal segment II longer than segment I, subequal in length to segment III (Figure 2A); scutellum well-developed, exposed (Figures 2C and $3 \mathrm{~A}$ ); hemelytron with membranous surface on sutural area. However, this new genus is distinguished from Vianaidinae by the distinctly areolate paranotum and hemelytron, which represent the diagnostic characters of the clade Tinginae + Cantacaderinae [1], whereas Vianaidinae has punctate paranotum and hemelytron. On the other hand, Burmavianaida gen. nov. does not match with the following diagnostic characters of the clade Tinginae + Cantacaderinae [1]: antennal segment II subequal in length to or shorter than segment I, shorter than segment III; scutellum undeveloped, often obscured by posterior process; hemelytron without membranous surface on sutural area. Therefore, Burmavianaida gen. nov. has intermediate characters between Tinginae + Cantacaderinae and Vianaidinae in general appearance. This new genus cannot be conclusively assigned to any of the extinct and extant subfamilies, but it may form an extinct lineage separated from the abovementioned two extant clades.

Some fossil insects of Kachin amber represent miniaturization compared to their extant close relatives [16-18], and relatively smaller fossil lace bugs (body length $2.0-3.0 \mathrm{~mm}$ ) have been found until now [13,14]. A particularly interesting feature of Burmavianaida anomalocapitata sp. nov. is its extremely small size. The length of the extant lace bugs ranges from approximately $2.0-8.0 \mathrm{~mm}$ [1], while the previously known smallest lace bug, is Coleopterodes liliputianum (Signoret, 1863) (Tinginae: Tingini), with the body length ranging from 1.57 to $1.90 \mathrm{~mm}$ [27]. However, the body length of this new species is only $1.40 \mathrm{~mm}$ (Figure 1A-C), representing the smallest species of the entire Tingidae. The observed smaller body size of lace bugs in Burmese amber, when compared to extant taxa, is an isolated case, whereas a similar phenomenon has been found in several species of Coleoptera and Hymenoptera as well [16-18,28-30]. The previous study [16] mentioned the miniaturization trend of insects in the mid-Cretaceous based on the discovery of the smallest paederine rove beetles together with the previous finding from the Kachin amber. Furthermore, the other study [18] tried to explain this miniaturization phenomenon as a result of random variation or paleo-environmental factors such as the warmer climate and lower oxygen concentration. Although the reason for the miniaturization phenomenon of insects in the mid-Cretaceous is still unclear due to the paucity of information, our discovery of the miniatured new species, and the previous studies $[13,14]$ indicates the possibility of this phenomenon in Tingidae, as already documented in beetles and wasps [16-18,28-30]. However, further studies and statistical assessments are needed to reveal the commonness of the miniaturization of lace bugs in the mid-Cretaceous. 


\section{Conclusions}

In this paper, we describe the 15th species of eighth genus of the extinct lace bug Burmavianaida anomalocapitata gen. et sp. nov. based on a well-preserved fossil from Kachin amber. Burmavianaida gen. nov., which undoubtedly matches the diagnostic characters of the family Tingidae, shares the diagnostic characters with two clades composed of three extant tingid subfamilies (Cantacaderinae + Tinginae) and Vianaidinae and may represent an extinct clade distinct from them. This unusual fossil taxon is the smallest species of Tingidae among over 2600 described species. The discovery of Burmavianaida gen. nov. supports a hypothesis of the miniaturization phenomenon of insects (part of Coleoptera, Hymenoptera, and possibly Heteroptera) in Kachin amber [16-18,26-28], but further studies are needed to corroborate this hypothesis.

Author Contributions: Conceptualization, J.S. and S.Y.; Methodology, J.S., S.Y. and Y.T.; Validation, J.S., S.Y. and Y.T.; Investigation, J.S. and S.Y.; Resources, J.S. and S.Y.; Data Curation, J.S. and S.Y.; Writing-Original Draft Preparation, J.S., S.Y. and Y.T.; Writing—Review and Editing, J.S., S.Y. and Y.T.; Visualization, J.S. and S.Y.; Supervision, J.S. and S.Y.; Project Administration, J.S. and S.Y.; Funding Acquisition, J.S. and S.Y. All authors have read and agreed to the published version of the manuscript.

Funding: This research was funded by the Grant-in-Aid for JSPS Fellows awarded to Jun Souma (JP20J20483) and Shûhei Yamamoto (JP20J00159) from the Japan Society for the Promotion of Science, Tokyo, Japan.

Data Availability Statement: All data generated or analyzed during this study are included in this published article. The higher-resolution images used in this study have been deposited in the figshare (https:// doi.org/10.6084/m9.figshare.14465400; accessed on 22 April 2021) and Zenodo repositories (https://doi.org/10.5281/zenodo.4709792; accessed on 22 April 2021).

Acknowledgments: We thank three anonymous reviewers and the Editor-in-Chief for their valuable comments and suggestions, which improved the manuscript. This work was partially supported by the Grant-in-Aid for JSPS Fellows awarded to JS (JP20J20483) and SY (JP20J00159) from the Japan Society for the Promotion of Science, Tokyo, Japan.

Conflicts of Interest: The authors declare no conflict of interest.

\section{References}

1. Schuh, R.T.; Weirauch, C. True Bugs of the World (Hemiptera: Heteroptera). Classification and Natural History, 2nd ed.; Siri Scientific Press: Manchester, UK, 2020; 768p.

2. de Laporte, F.L. Essai d'une classification systématique de l'ordre des Hémiptères (Hémiptères Hétéroptères, Latr.). Mag. Zool. 1833, 2, 17-88.

3. Stål, C. Enumeratio Hemipterorum. 3. Kungliga Svenska Vetenskapsakademiens Handlingar 1873, 11, 1-163.

4. Kormilev, N.A. A new myrmecophil family of Hemiptera from the delta of Río Paraná, Argentina. Rev. Ecuat. Entomol. Parasitol. 1955, 2, 465-477.

5. Montagna, M.; Strada, L.; Dioli, P.; Tintori, A. The Middle Triassic Lagerstätten of Monte San Giorgio reveals the oldest lace bugs (Hemiptera: Tingidae): Archetingis ladinica gen. n. sp. n. Riv. Ital. Paleontol. Strat. 2018, 124, 35-44.

6. Popov, Y.A. New fossil Hemiptera (Heteroptera + Coleorrhyncha) from the Mesozoic of Mongolia. Neues Jahrb. Geol. Paläontol. 1989, 1989, 166-181. [CrossRef]

7. Perrichot, V.; Nel, A.; Guilbert, E.; Néraudeau, D. Fossil Tingoidea (Heteroptera: Cimicomorpha) from French Cretaceous amber, including Tingidae and a new family, Ebboidae. Zootaxa 2006, 1203, 57-68. [CrossRef]

8. Golub, V.B.; Popov, Y.A. New species of Tingidae (Insecta: Hemiptera: Heteroptera) from the Lower Cretaceous of Transbaikalia. Paleontol. J. 2008, 42, 86-89.

9. Popov, Y.A.; Golub, V.B. A new tribe, genus and four species of lace bugs (Hemiptera: Heteroptera: Tingidae) from the Upper Cretaceous of Southwestern Kazakhstan. Paleontol. J. 2019, 53, 155-164. [CrossRef]

10. Ross, A.J. Burmese (Myanmar) amber checklist and bibliography 2018. Palaeoentomology 2019, 2, 22-84. [CrossRef]

11. Ross, A.J. Supplement to the Burmese (Myanmar) amber checklist and bibliography, 2019. Palaeoentomology 2020, 3, 103-118. [CrossRef]

12. Ross, A.J. Supplement to the Burmese (Myanmar) amber checklist and bibliography, 2020. Palaeoentomology 2021, 4, 57-76. [CrossRef]

13. Golub, V.B.; Heiss, E. Three new species of the lacebug genus Tingiometra from Cretaceous Burmese amber (Hemiptera: Heteroptera: Tingidae: Tingiometrinae). Zootaxa 2020, 4767, 531-542. [CrossRef] 
14. Poinar, G., Jr.; Vega, F.E. A lacewing bug, Paleoanomala aptenus gen. et sp. nov. (Hemiptera: Tingidae), in mid-Cretaceous Burmese Amber. Biosis Biol. Syst. 2020, 1, 65-71. [CrossRef]

15. Heiss, E.; Guilbert, E. A new species of Burmacader Heiss \& Guilbert, 2013 from Cretaceous Burmese amber (Hemiptera, Heteroptera, Tingidae). Palaeoentomology 2021, 4, 30-33. [CrossRef]

16. Żyła, D.; Yamamoto, S.; Jenkins Shaw, J. Total-evidence approach reveals an extinct lineage of Paederinae rove beetles from Cretaceous Burmese amber. Palaeontology 2019, 62, 935-949. [CrossRef]

17. Yamamoto, S.; Takahashi, Y. First and oldest Leptochirini rove beetles illuminate diverse cephalic structures in the Cretaceous (Coleoptera: Staphylinidae: Osoriinae). Syst. Entomol. 2019, 44, 588-611. [CrossRef]

18. Liu, Y.; Tihelka, E.; Huang, D.; Tian, L.; Cai, C. A new fossil species of the rove beetle subfamily Protopselaphinae (Coleoptera: Staphylinidae) from mid-Cretaceous Burmese amber. Hist. Biol. 2020, 1-6. [CrossRef]

19. Shi, G.; Grimaldi, D.A.; Harlow, G.E.; Wang, J.; Wang, J.; Yang, M.; Lei, W.; Li, Q.; Li, X. Age constraint on Burmese amber based on U-Pb dating of zircons. Cretaceous Res. 2012, 37, 155-163. [CrossRef]

20. Mao, Y.Y.; Liang, K.; Su, Y.T.; Li, J.G.; Rao, X.; Zhang, H.; Xia, F.Y.; Fu, Y.Z.; Cai, C.Y.; Huang, D.Y. Various amberground marine animals on Burmese amber with discussions on its age. Palaeoentomology 2018, 1, 91-103. [CrossRef]

21. Yu, T.T.; Kelly, R.; Mu, L.; Ross, A.; Kennedy, J.; Broly, P.; Xia, F.Y.; Zhang, H.C.; Wang, B.; Dilcher, D. An ammonite trapped in Burmese amber. Proc. Natl. Acad. Sci. USA 2019, 116, 11345-11350. [CrossRef]

22. Balashov, I. The first records of mollusks from mid-Cretaceous Hkamti amber (Myanmar), with the description of a land snail, Euthema myanmarica n. sp. (Caenogastropoda, Cyclophoroidea, Diplommatinidae). J. Paleontol. 2021, 1-10. [CrossRef]

23. Drake, C.J.; Ruhoff, F.A. Lacebugs of the world, a catalog (Hemiptera: Tingidae). Bull. U. S. Natl. Mus. 1965, 243, 1-634. [CrossRef]

24. Montemayor, S.I.; Carpintero, D.L. A new macropterous genus with a new species of Vianaididae (Heteroptera, Tingoidea, Vianaididae) from Peru. Stud. Neotrop. Fauna Environ. 2007, 42, 133-136. [CrossRef]

25. Schuh, R.T.; Cassis, G.; Guilbert, E. Description of the first recent macropterous species of Vianaidinae (Heteroptera: Tingidae) with comments on the phylogenetic relationships of the family within the Cimicomorpha. J. N. Y. Entomol. Soc. 2006, 114, 38-53. [CrossRef]

26. Heiss, E.; Golub, V.B.; Popov, Y.A. A new subfamily, genus and species of Tingidae (Hemiptera: Heteroptera) from Burmese amber. Z. Arb.gem. österr. Entomol. 2015, 67, 1-9.

27. Montemayor, S.I.; Coscarón, M.C. Taxonomic revision of Coleopterodes Philippi (Heteroptera: Tingidae). Zootaxa 2005, 1092, 31-38. [CrossRef]

28. Beutel, R.G.; Zhang, W.W.; Wappler, T.; Bai, M.; Pohl, H. A miniaturized beetle larva in Cretaceous Burmese amber: Reinterpretation of a fossil "strepsipteran triungulin". Insect Syst. Evol. 2016, 47, 83-91. [CrossRef]

29. Li, Y.-D.; Yamamoto, S.; Huang, D.-Y.; Cai, C.-Y. A miniaturized ommatid beetle in mid-Cretaceous Burmese amber (Coleoptera: Archostemata: Ommatidae). Pap. Avulsos Zool. 2020, 60, e20206063. [CrossRef]

30. Li, L.; Kopylov, D.S.; Shih, C.; Ren, D. The first record of Ichneumonidae (Insecta: Hymenoptera) from the Upper Cretaceous of Myanmar. Cretaceous Res. 2017, 70, 152-162. [CrossRef] 